David R. Bevan MB MRCP FFarCs, Francois Donati PHD MD

\title{
Succinylcholine apnoea: Attempted reversal with anticholinesterases
}

\begin{abstract}
Anticholinesterases were administered in an attempt to antagonize prolonged neuromuscular blockade following the administration of succinylcholine in a patient later found to be homozygous for arypical plasma cholinesterase. Edrophonium $10 \mathrm{mg}$, given 74 min after succinylcholine, when train-of-four stimulation was characteristic of phase II block, produced partial antagonism which was not sustained. Repented doses of edrophomium to $70 \mathrm{mg}$ and neostigmine to $2.5 \mathrm{mg}$ did not antagonize or augment the block. Spontaneous respiration recommenced 200 min after succinylcholine adninistration. It is concluded that anticholinesterases are only partially effective in restoring neuromuscular function in succinylcholine apnoea despite muscle witch activity typical of phase II block.
\end{abstract}

\section{Key words} NEUROMUSCULAR RELAXANTS: succinylcholine; COMPLICATIONS: apNOER; ANTAGONISTS, NEUROMUSCULAR RELAXANTS: neostigmine, edrophonium.
The use of anticholinesterases to antagonize prolonged neuromuscular blockade (NMB) after succinylcholine administration to patients with atypical plasma cholinesterase has had variable success. Vickers ${ }^{1}$ concluded that anticholinesterase agents prolonged the block in succinylcholine-sensitive individuals and that electromyographic responses, at least using tetanic stimulation, may not identify the change from phase I to phase II block. Savarese et al. ${ }^{2}$ using train-of-four stimulation, studied four patients with prolonged succinylcholine apnoea. After surgery all arrived in the recovery room with a train-of-four ratio (T4/T1) of less than 0.5 , characteristic of phase II block but this was reversed successfully with anticholinesterase in only three. More recently, Viby-Mogensen ${ }^{3}$ has recommended the combination of human cholinesterase and a cholinesterase inhibitor to accelerate recovery from such a block.

Recently, we were able to record the progress of the NMB in a patient who was given succinylcholine and who was later shown to be homozygous for atypical plasma cholinesterase. Attempts were made to restore neuromuscular function with anticholinesterases when the appearances of the block were typical of phase II, T4/T1<0.5.

\section{Case report}

A 40-year-old woman, $157 \mathrm{~cm}$ tall and weighing $51 \mathrm{~kg}$ was scheduled for laparotomy for chronic lower abdominal pain. Her past medical history included a cholecystectomy at age 26 and an abdominal hysterectomy three years later. Both operations were performed under general anaesthesia, the details of which were unavailable. The patient denied problems associated with anaesthesia in the postoperative period. However, her husband 


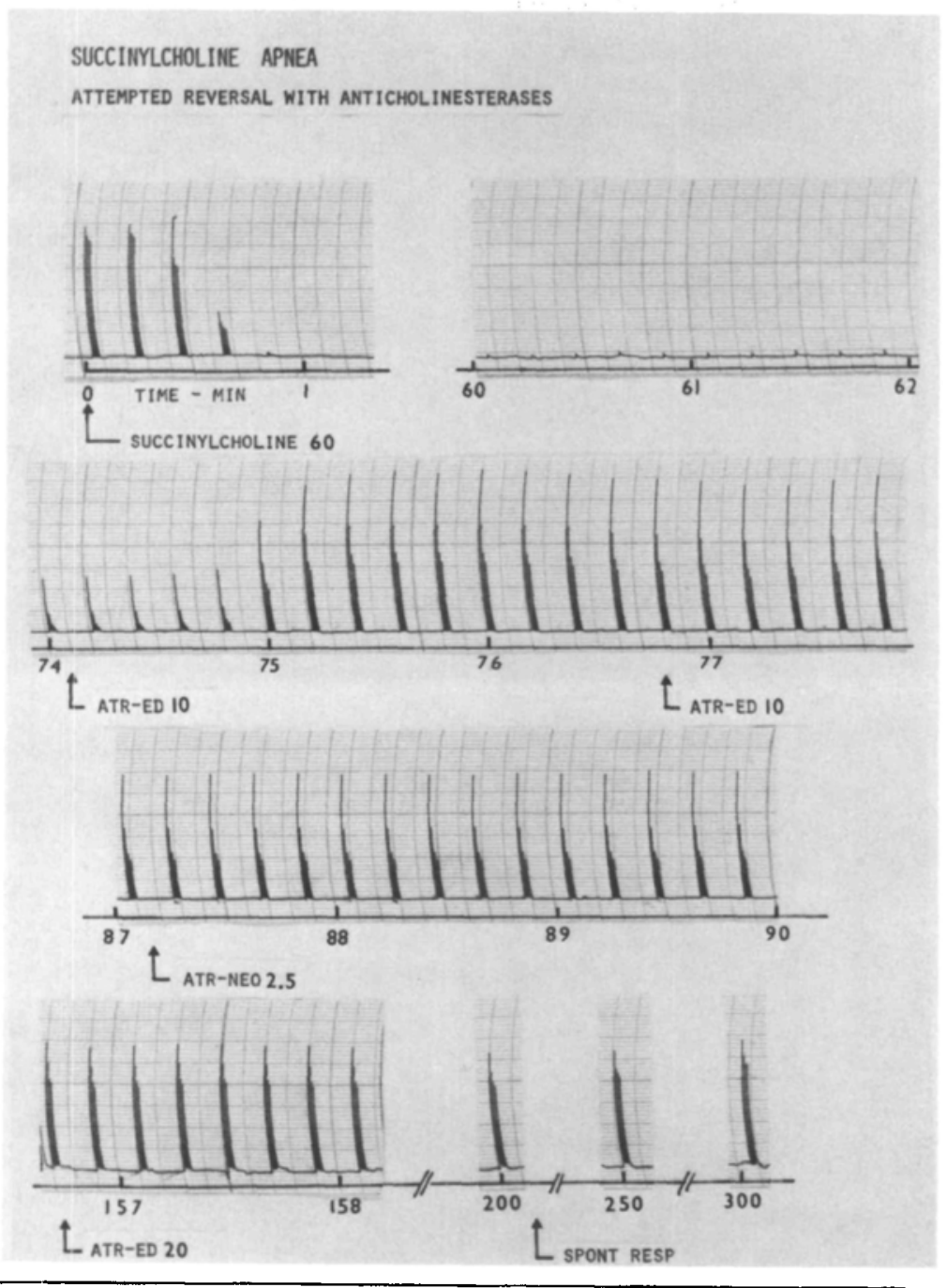

FIGURE Train-of-four recording of neuromuscular activity following attempted antagonism with atropine and edrophonium (ATR-ED) or atropine and neostigmine (ATR-NEO) of prolonged NMB in a patient homozygous for atypical plasma cholinesterase. Time is shown on the $\mathrm{x}$-axis and force of contraction on the $y$-axis. See text for details.

admitted later that recovery after the cholecystectomy seemed to be prolonged.

At the present admission the patient was otherwise healthy. She denied allergies or family problems associated with anaesthesia. Examination of the cardiovascular and respiratory system was normal. Laboratory data showed a haemoglobin of $128 \mathrm{~g} / \mathrm{l}$, and normal plasma electrolytes, urea and creatinine. Serum calcium, bilirubin, albumen, total protein, glutamic-oxaloacetic transaminase, glutamic-pyruvic transaminase, lactic dehydrogenase and alkaline phosphatase were all normal. 
One hour before anaesthesia, she was given morphine $7.5 \mathrm{mg}$ and atropine $0.4 \mathrm{mg}$ intramuscularly. On arrival in the operating room blood pressure was measured, electrocardiogram was recorded, an intravenous infusion was commenced in the right arm and stimulating needles were inserted subcutaneously over the left ulnar nerve for neuromuscular monitoring. The left hand and forearm were immobilized in a plaster cast and the thumb was connected to a force displacement transducer (Grass FT 10) so that the response of the adductor pollicis to ulnar nerve stimulation could be recorded on a Grass Polygraph pen-and-ink recorder. The hand and forearm were covered with gauze pads so that the skin temperature of the thumb was maintained above $33^{\circ} \mathrm{C}$.

Anaesthesia was induced with thiopentone, 275 $\mathrm{mg}$, and maintained with 70 per cent nitrous oxide in oxygen with isoflurane, $0.5-1$ per cent, given initially via a facemask and a Mapleson A circuit during spontaneous ventilation. Ulnar nerve stimulation was commenced, after induction of anaesthesia, with trains-of-four square wave impulses of $0.2 \mathrm{msec}$ duration and $2 \mathrm{~Hz}$ frequency every $12 \mathrm{sec}$ using a Grass $\$ 48$ stimulator and SILS isolation unit Control twitch measurements were made after a stable baseline had been obtained. Then, succinylcholine $60 \mathrm{mg}$ was given which was followed by paralysis within 1 min (Figure). The trachea was intubated and the patient was ventilated throughout surgery to normocapnia as assessed by end-tidal carbon dioxide tension measured with a HewlettPackard HP capnograph.

The subsequent course of the NMB is shown in the Figure. There was total absence of response to nerve stimulation until nearly $60 \mathrm{~min}$ after administration of succinylcholine. This was followed by slow recovery of first twitch tension (TI) with considerable train-of-four fade. At $74 \mathrm{~min}$, when T1 was about 40 per cent control and the train-offour ratio was less than 0.1 , the twitch response was typical of phase II block. Thus, an anticholinesterase, edrophonium $10 \mathrm{mg}$, was given with atropine. This was followed by rapid, partial reversal of the NMB so that $90 \mathrm{sec}$ after its administration T1 was 120 per cent of control and T4/T1 was 0.43 . This antagonism was not sustained. Two minutes later, $\mathrm{T} 1$ had decreased slightly to 106 per cent and $\mathrm{T} 4 / \mathrm{T} 1$ to 0.37 . Further doses of anticholinesterases, edrophonium to a total of $70 \mathrm{mg}$ and neostigmine to
$2.5 \mathrm{mg}$, had no effect on neuromuscular activity: the block was neither antagonized nor augmented. Ninety minutes after the administration of succinylcholine $(\mathrm{T} 1=100$ per cent, $\mathrm{T} 4 \mathrm{~T} 1=0.33)$, the ventilator was disconnecled and the patient made attempts at spontancous respiration. However, this was associated with a gradual increase in end-tidal $\mathrm{CO}_{2}$ to $60 \mathrm{mmHg}$, when positive pressure ventilation was reinstated. At the end of surgery, the patient was transferred to the recovery room where ventilation and neuromuscular monitoring were continued. Gradual recovery of neuromuscular function ensued and spontaneous respiration recommenced at $200 \mathrm{~min}$ ( $\mathrm{T} 1=90$ per cent, T4/T1 = $0.7)$. Five hours after administration of succinylcholine some train-of-four fade was still present $(\mathrm{T} 4 / \mathrm{Tl}=0.8)$. There were no further postoperative complications. Blood was taken, 24 hours later, for plasma cholinesterase assay which was characteristic of the homnzygous atypical gene:

$\begin{array}{lll}\text { total activity } & 24.4 \mathrm{U} & \text { (normal 43-69) } \\ \text { dibucaine inhibition } & 29 \% & \text { (normal 78-85) } \\ \text { fluoride inhibition } & 24 \% & \text { (normal 57-64) } \\ \text { chloride inhibition } & 52 \% & \text { (normal 11-20) }\end{array}$

Later testing of the patient's two children showed them to be a typical heterozygotes.

\section{Discussion}

Fade in the response of the adductor pollicis to train-of-four stimulation of the ulnar nerve is characteristic of non-depolarizing or phase II NMB. When present it predicts that anticholinesterases will antagonize the non-depolarizing block of curare-like drugs ${ }^{4}$ or the phase II block of succinylcholine ${ }^{5}$ By these criteria the NMB in the present patient at $74 \mathrm{~min}$ ( $\mathrm{T} 1$ depression of 58 per cent, $\mathrm{T} 4 / \mathrm{T} 1$ of $<0.1$ ) suggested that the block should be antagonized with anticholinesterases. Indeed, the degree of fade to train-of-four stimulation was greater than that reported for the same degree of $\mathrm{T} 1$ depression with non-depolarizing NMB. ${ }^{6}$ Edrophonium was chosen first because, when used to antagonize pancuronium, it produced better restoration of T4/T1 fade for the same degree of $T 1$ depression than did neostigmine. ${ }^{7}$

In practice, these hypotheses could not be supported. Although edrophonium $10 \mathrm{mg}$ was followed by partial reversal of NMB, this was neither 
sustained nor improved by subsequent administration of either edrophonium or neostigmine. The degree of recovery of neuromuscular function was inadequate for spontaneous respiration.

Viby-Mogensen ${ }^{3}$ suggested that in patients with prolonged response to succinylcholine, depolarizing NMB persisted because of the presence of succinylcholine in the palsma. Edrophonium was said to be effective in antagonizing the nondepolarizing component of the block but may potentiate any residual depolarizing component. Human cholinesterase was recommended for the reversal of depolarizing NMB. This explanation does not account for the observations made in our patient because she showed the train-of-four fade of non-depolarizing block and the block was never augmented after either anticholinesterase. Thus, the NMB had the appearances only of a non-depolarizing block which could not be antagonized with anticholinesterase. Irrespective of the exact mechanism of action, the diagnosis of phase II block by assessment of train-of-four fade does not guarantee successful antagonism by anticholinesterases in patients homozygous for atypical cholinesterase.

It is possible that repeated doses of anticholinesterases delayed recovery from NMB in our patient by decreasing the already low plasma cholinesterase activity. ${ }^{8,9}$ This possibility must be weighed against the favourable response of some succinylcholinesensitive patients to anticholinesterases. ${ }^{10,11}$ This report also suggests that if edrophonium produces an initial antagonism of NMB followed by its intensification, then no further anticholinesterase should be given. We agree with Viby-Mogensen that the NMB will last until plasma concentrations of succinylcholine decrease to sub-paralytic levels either by redistribution and excretion or by metabolism induced with exogenous cholinesterase.

\section{References}

1 Vickers $M D A$. The mismanagement of suxamethonium apnoea. Br J Anaesth 1963; 35: 260-8.

2 Savarese JJ, Ali HH, Murphy JD, Padget C, Lee $C-M$, Ponitz $J$. Train-of-four nerve stimulation in the management of prolonged neuromuscular block following succinylcholine. Anesthesiology 1975; 42: 106-11.

3 Viby-Mogensen J. Succinylcholine neuromuscular blockade in subjects homozygous for atypical plasma cholinesterase. Anesthesiology 1981; 55: 429-34.
4 Ail HH, Savarese JJ. Monitoring of neuromuscular function. Anesthesiology 1976; 45: 216-49.

5 Lee C. Dose relationships of phase II, tachyphylaxis and train-of-four fade in suxamethonium-induced neuromuscular block in man. Br J Anaesth 1975; 47 : $841-5$.

6 Williams NE, Webb SN, Calvey TN. Differential effects of myoneural blocking drugs on neuromuscular transmission. Br J Anaesth 1980; 52: 1111-5.

7 Donati F, Ferguson A, Bevan DR. Twitch depression and train-of-four ratio after antagonism of pancuronium with edrophonium, neastigmine or pyridostigmine. Anesth Analg 1983; 62: 314-6.

8 Baraka $A$. Suxamethonium-neostigmine interaction in patients with normal or atypical cholinesterase. Br J Anaesth 1977; 49: 479-84.

9 Baraka A, Wakid N, Mansour R, Haddad W. Effect of neostigmine and pyridostigmine on the plasma cholinesterase activity. Br J Anaesth 1981; 53: 849-51.

10 Donati $F$, Bevan $D R$. Effect of enflurane and fentanyl on the clinical characteristics of long-term succinylcholine infusion. Can Anaesth Soc J 1982; 29: $59-64$.

11 Miller RD, Stevens $W C$. Antagonism of succinylcholine paralysis in a patient with atypical pscudocholinesterase. Anesthesiology 1972; 36: 511-3.

\section{Résumé}

On a tenté, à l'aide d' anticholinestérasiques, de produire lantagonisme d'un bloc neuromusculaire prolongé causé par l'admintstration de $1.2 \mathrm{mg} \cdot \mathrm{kg}^{-1}$ de succinylcholine chez une patiente qui s'est avérée être homozy. gote pour la cholinesterrase plasmatique atypique. On a donné $10 \mathrm{mg}$ d' édrophonium 74 minutes après l'administration de succinylcholine lorsque le train de quatre stimulations (irain-of-four) possédait les caractéristiques d' un bloc de phase ll. Il en a résulté un antagonisme partiel et non soutenu. Le blac neuromusculaire est demeuré inchangé à la suite de l'administration répétée d'édrophonium, jusqu'à une dose totale de $70 \mathrm{mg}$, et $2.5 \mathrm{mg}$ de néostigmine. La patiente s'est mise à respirer spontanément 200 minutes après la dose de succinylcholine. On en conclut que les anticholinestérasiques ne sont que partiellement efficaces dans le traitement d'une apnée prolongée due d̀ la succinylcholine et ce, en dépit des contractions stimulées caractéristiques d' un bloc de phase II. 